\title{
ILLUSTRATIONS OF EARTHWORMS OCCURING IN AND AROUND CHENNAI, INDIA
}

\author{
V.I. Ramzan Begum ${ }^{1}$ and Sultan Ahmed Ismail ${ }^{2}$ \\ ${ }^{1}$ Institute of Research in Soil Biology and Biotechnology, The New College, Chennai, Tamil Nadu 600014, India. \\ ${ }^{2}$ Corresponding author: Ecoscience Research Foundation, Plot 98, Baaz, Nagar, 3/621 East Coast Road, Palavakkam, Chennai, \\ Tamil Nadu 600041, India. \\ ${ }^{2}$ Email: sultan_ismail@vsnl.com
}

\begin{abstract}
Earthworms were collected from Chennai and its environs for taxonomic listing and to prepare a brief guide for identification by budding vermiculturists. Earthworm species were identified using existing taxonomic keys. Drawida scandens, Lampito mauritii, Perionyx excavatus, Perionyx sansibaricus, Octochaetona barnesi, Octochaetona pattoni, Octochaetona serrata, Octochaetona thurstoni, Dichogaster bolaui and Eudrilus eugeniae have been recorded. D. bolaui was the smallest while $O$. thurstoni was the largest species in size observed. Fully mature adults of the common species collected over a period of time from sites in and around Chennai are illustrated. Among the species, Eudrilus eugeniae does not occur naturally and are procured from external sources for vermicomposting units.
\end{abstract}

\section{Keywords}

Earthworms, Chennai, illustrations

$\begin{array}{lr}\text { Abbreviations } \\ \text { Cl-Clitellum } & \text { CO - Cushions (genital markings) } \\ \text { FP - Female pores } & \text { MF - Male field } \\ \text { MP - Male pores } & \text { PM - Genital papillae } \\ \text { S - Setae } & \text { SP - Openings of spermathecae }\end{array}$

\section{Introduction}

An upsurge in interest to study earthworms and their application in vermiculture and vermicompost production and due to the number of students opting for such projects in their post graduate and research levels, it is becoming increasingly necessary that short communications for identification of available earthworm species is made possible. This communication is based on one such need. Attempts have been made to keep the description simple.

Earthworms occur all over the world, but only rarely in deserts, areas under constant snow and ice, mountain ranges and areas almost entirely lacking in soil and vegetation (Edwards \& Bohlen, 1996).

Earthworms belong to the Order Oligochaeta of the Phylum Annelida. Oligochaetes are bilaterally symmetrical coelomate invertebrates with internal and external metameric segmentation throughout the body. Oligochaetes are often divided into two convenient groups Microdrili and Megadrili. During the last decade and half (Ismail, 1997) much taxonomic work on Indian earthworms has been carried out by Julka $(1975,1976 a, b, 1977$, 1978, 1979, 1981, 1983, 1993), Jamieson (1977) and Easton(1982).

Taxonomic characters of earthworms (Julka, 1988)

Based on growth stage earthworms are generally classified into juveniles, aclitellates, clitellates or adults, and post sexual worms.

External characters that are important in taxonomy include colour, body form, size, segmentation, prostomium, dorsal pores, clitellum, setae, genital pores, genital markings, tumescences and tubercula pubertatis, and nephridiopores.

Taxonomically important internal characters include pigmentation, septa, digestive system, vascular system, reproductive system, excretory system and accessory glands.

\section{Materials and Methods}

Earthworms were placed in a beaker containing water and narcotised by adding $70 \%$ ethanol drop by drop. They were then transferred to a flat-bottomed container with $10 \%$ formaldehyde and placed horizontally straight overnight. Finally they were transferred to vials of requisite sizes. The preservative 
was changed within a week, especially for larger worms for best results.

Prior to dissection, the worm's external characters e.g. shape of prostomium, location of genital and nephridial apertures, and form and extent of clitellum were recorded. The worm was then pinned in a dissecting dish containing water, by fine entomological pins, taking care to avoid injury to the prostomium. Using a fine scissors or scalpel or even a sharp razor blade, the body was cut open longitudinally slightly to the left or right side of the mid-dorsal line in order to avoid damage to the dorsal pores. By carefully cutting the septa, the flaps of the body wall were pinned out sideways with a fine pair of forceps, preferably first at the post-prostatic region and then continuing forward, care being taken to record the missing septa in the gizzard region. To determine the presence of oesophageal calciferous lamellae and openings of calciferous glands, it was necessary to cleave open the oesophagus along the mid-dorsal line. The beginning of the intestine and the form of typhlosole was determined by cutting just below the mid dorsal line on one side of the intestine. Penial and copulatory setae were removed along with their enlarged follicles from inside as pulling them from outside would damage their structure.

The species were identified using standard monographs (Stephenson, 1923; Julka, 1988).

\section{Following common species of earthworms were recorded}

\section{Order: Moniligastrida}

\section{Family: Moniligastridae}

Genus: Drawida Michaelsen

\section{Drawida scandens Rao}

\section{External characters}

Length 40-50mm, diameter 1.50-1.75mm. Segments about 140170. Colour dark bluish grey, brown or olive. Prostomium prolobous. Setae, eight per segment, closely paired, large and prominent. Male pores two pairs, first pair in 9/10, the second pair over the groove of $10 / 11$, just outside the line of setae $b$, in the antero-lateral angles of a thickened median patch that occupies the ventral surface of xi, pushing forwards groove 10/ 11. Pair of genital papillae internally with prostate-like tubular glands is observed in segment ix. Female pores appear in 11/12 between the lines $a$ and $b$.

\section{Internal characters}

Septa 6/7 - 8/9 considerably thickened, 5/6 thin, 9/10 and a few following also slightly thickened. Two gizzards found in xiii and xiv. Testis sacs extend into ix and $\mathrm{x}$. No ovarian chamber; ovisacs may extend back to xv. Spermathecal atrium found to be relatively large, ovoid and sac-like, duct entering at the base.

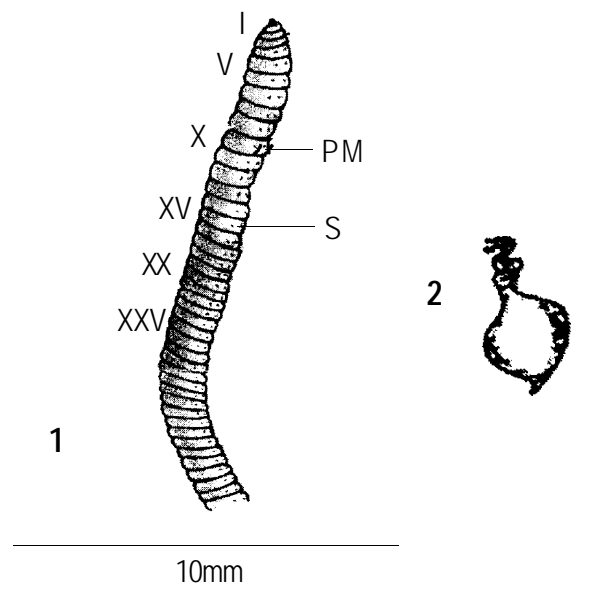

Figures 1-2. Drawida scandens Rao 1 - External characters; 2 - Spermatheca $(\times 30)$

\section{Order: Haplotaxida \\ Super family: Megascolecoidea \\ Family: Megascolecidae \\ Genus: Lampito Kinberg \\ Lampito mauritii Kinberg}

External characters

Length 72-152mm, diameter 3.5-5.5mm, total segments 126-179. Colour dorsally is greyish, brownish or yellowish with purplish tinge at anterior end. Prostomium is epilobic with tongue 1/2, closed. First dorsal pore starts on $10 / 11$ or $11 / 12$. Setal arrangement is perichaetine, 40-50 setae per segment in the preclitellar region, while post clitellar segments have 30 to 44 setae per segment. Clitellum annular extends from xiv-xvii. Male pores paired superficial on xviii, about 1/4th circumference apart. The female pores minute, approximated in very close to the middle line, on xiv. Spermathecal pores three pairs at 6/7, 7/8, 8/9. No genital markings.

\section{Internal characters}

Septa $7 / 8$ to $12 / 13$ slightly thickened, no missing of septa, gizzard distinct in vi; no calciferous gland nor intestinal caecum. Intestine starts from $\mathrm{xv}$, typhlosole starts from $\mathrm{xv}$, but insignificant or rudimentary. Last pair of hearts observed in xiii. Holandric, seminal vesicles in ix and xii irregularly cut up into small lobes, prostate lobular, small. Spermathecae with elongated ampullae, constricted in the middle, duct not distinctly marked off, two diverticulae, club-shaped, opposite to each other with each ampulla. Penial setae distally ornamented with triangular teeth, tip pointed or bifurcated, but are a distinct trident at higher magnifications (Ismail, 1982). This species is bioluminescent (Ismail \& Kaleemurrahman, 1981). 

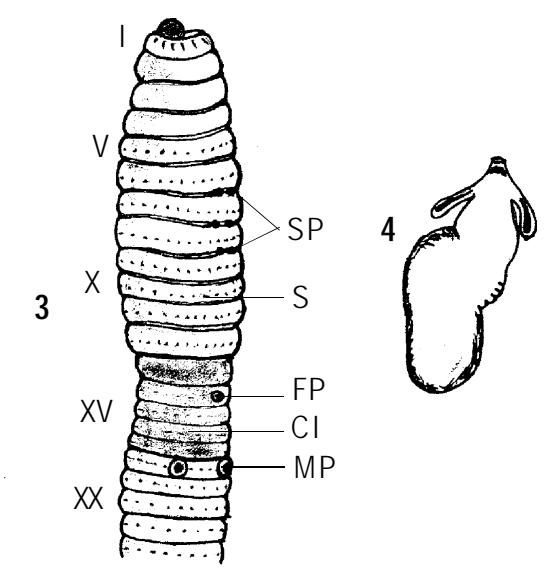

$10 \mathrm{~mm}$

Figures 3-5. Lampito mauritii Kinberg 3 - External characters; 4 - Spermatheca (x15); 5 - Penial seta (x200)

\section{Remarks}

This is the most common earthworm species in the loamy soils of Chennai and most of southern India. Associated occasionally with L. mauritii is noticed Lampito bouchei Jamieson. Though it looks similar to L. mauritii, this species is characterised with eight setae per segment, only two pairs of spermathecae, seminal vesicles in XIII, and absence of typhlosole and penial setae.
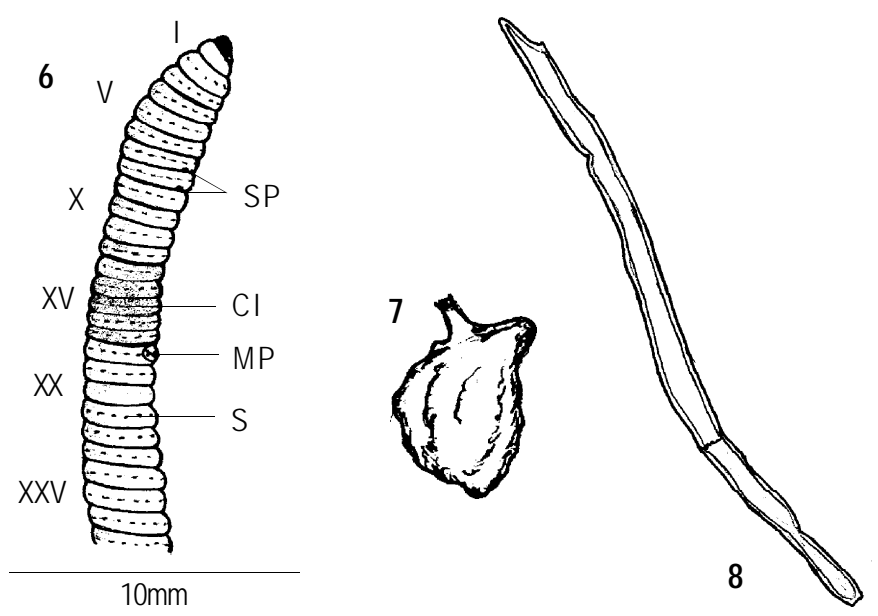

Figure 6-8. Perionyx excavatus Perrier 6- External characters; 7 - spermatheca (x30); 8 - penial seta (x100)

\section{Genus: Perionyx Perrier \\ Perionyx excavatus Perrier}

External characters

Length $65-150 \mathrm{~mm}$, diameter $3-4.5 \mathrm{~mm}$, total segments $90-155$. Colour deep purple to reddish brown dorsally but pale ventrally. Prostomium epilobous. First dorsal pore appears in $4 / 5$, in some cases 5/6. Setae small, perichaetine, $42-52$ per segment. Clitellum thin often indistinct, annular on xiii-xvii. Male pores approximated, in a small oval depressed male field, each on small transverse slits on xviii. Spermathecal pores paired, near mid ventral line as apart as male pores on 7/8 and 8/9. Body dorso-ventrally flattened and the posterior portion more tapering than the anterior. No genital markings.

\section{Internal characters}

No missing of septa or any septa specially thickened. Gizzard not prominent, vestigial in vi in some cases. Oesophagus widened in xiii. Intestine begins in Xv. Last pair of hearts seen in xii. Holandric; seminal vesicles two pairs, in xi and xii, the last pairs extend up to $14 / 15$. Prostates small, racemose confined to xviii, somewhat fissured, compact, sessile on body wall; prostatic duct short, more or less straight. Spermathecae are two pairs in viii and ix, each with ovoid ampulla and a short, narrow duct; diverticulae many, very small wart like on the duct. Penial setae in groups and their distal ends ornamented with many rings of pointed spines.

\section{Remarks}

This is commonly found in compost heaps and is also commonly referred to as the Indian Blue.

\section{External characters}

\section{Perionyx sansibaricus Michaelsen}

Length 30-80mm; diameter 2-3mm. Segments 85-120. Colour purple dorsally but pale ventrally. Prostomium epilobous. First dorsal pore may be found at $2 / 3$, but varies. Clitellum is ringshaped, xiii-xvii. Male area somewhat variable; depressed, broader than long, taking up the whole of the length of xviii; sometimes the whole area is not depressed, but only two crescentric depressions, one in front and one behind a transverse ridge bearing the pores. Spermathecal pores 6/7, 7/8 and 8/9, near the middle line.

\section{Internal characters}

No septa noticeably thickened. Gizzard entirely vestigial, in vi. Oesophagus may be wider, and the wall ridged and vascular, in xiii, or there may be no such change. Last heart in xii. Testes and funnels free in $\mathrm{x}$ and $\mathrm{xi}$. Seminal vesicles in xi and xii, racemose. Prostates with large deeply indented glandular portion; duct thin, rather short, straight. Spermathecal ampulla pear shaped, narrowing to a short duct; a small thickly pear-shaped diverticulum. No penial setae. 


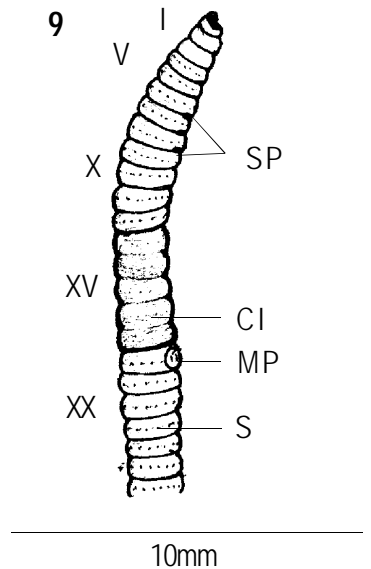

Figures 9-10. Perionyx sansibaricus Michaelsen 9 - External characters; 10 - Spermatheca (x15)

\section{Remarks}

This species is also commonly found in compost heaps

\section{Family: Octochaetidae Genus: Dichogaster Beddard Dichogaster bolaui (Michaelsen)}

\section{External characters}

Length 20-40mm, diameter 2mm. Segments ca. 80-110. Colour brown on preservation. Dorsal pores present from 5/6. Clitellum xiii, xiv-xviii, xix. Setae, eight per segment and closely paired. Male pores minute, in seminal groves on the setal arc of xviii, prostatic pores minute at the ends of seminal groves on xvii and xix. Seminal grooves slightly concave between the setal arcs of $x v i i$ and xix. Female pores single, median in between xiv and xv. Spermathecal pores on 7/8/9.

\section{Internal characters}

Septa 4/5, 7/8 - 12/13 slightly muscular. Gizzards between v and viii. Prostates almost straight. Seminal vesicles vestigial in $\mathrm{xi}$ and xii. Testes and male funnels two pairs. Penial setae ornamented with a few to several triangular teeth, tip hooked. Each spermathecal ampulla sac-like with a thick duct. Diverticulum small, club shaped and joins the middle of the duct.

\section{Remarks}

This species is usually associated with high organic matter such as gardens, kitchen waste dumps, composting units, etc.

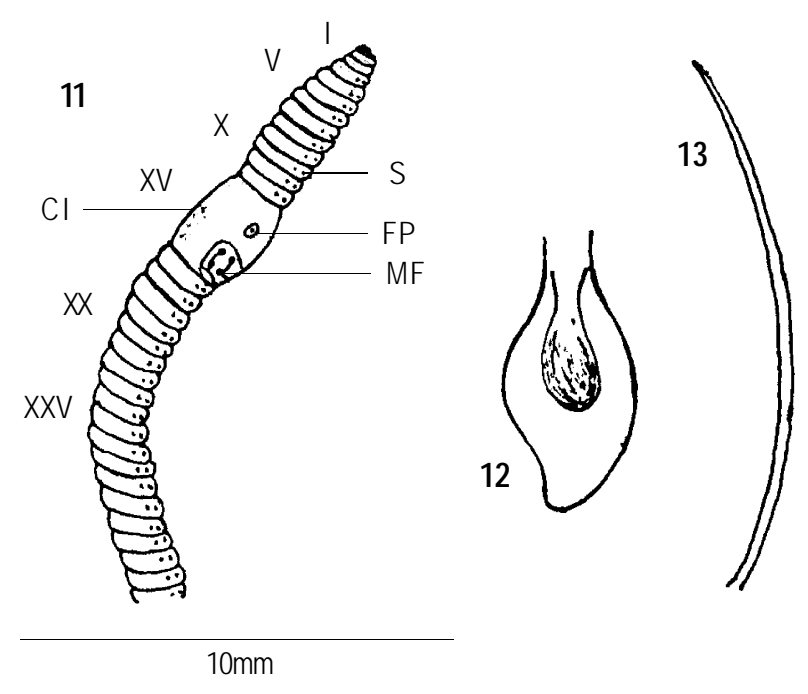

Figure 11-13. Dichogaster bolaui (Michaelsen) 11- External characters; 12 - Spermatheca (x60); 13 - Penial seta $(x 100)$

\section{Family: Octochaetidae Genus: Octochaetona Gates Octochaetona barnesi (Stephenson) \\ External characters}

Length $75 \mathrm{~mm}-100 \mathrm{~mm}$, diameter $3.5 \mathrm{~mm}, c a .200$ segments. Prostomium epilobic, tongue open. First dorsal pore 12/13. Clitellum xiii-xvii. Setae eight per segment. On viii, copulatory setae are surrounded by epidermal tumescences. Male genital field depressed on posterior portion of xvii and anterior portion of xix. Male pores minute, at $b$; prostatic pores minute, at a; seminal grooves concave between setal arcs of xvii and xix. Female pores paired. Spermathecal pores minute, in 7/8/9, at a. Genital markings usually absent; when present, paired oval, postsetal on ix and on 14/15.

\section{Internal characters}

Septa 4/5, 8/9-11/12 muscular, 5/6/7/8 absent. Gizzard between septa $4 / 5$ and 8/9. Intestine begins in xvii. Last pair of hearts in xiii. Holandric, testes and male funnels free, in $\mathrm{x}$ and $\mathrm{xi}$; seminal vesicles in ix and xii. Penial setae ornamented with circles of fine spines, ectal and flattened and slightly hollowed, $1.5 \mathrm{~mm}$ long, $25 \mu$ diameter. Each spermatheca with a cylindrical ental diverticulum, duct shorter than ampulla. Copulatory setae ornamented with semi-circular depressions with sharp margins, tip claw-shaped. $0.8 \mathrm{~mm}$ long, $20 \mu$ diameter. 


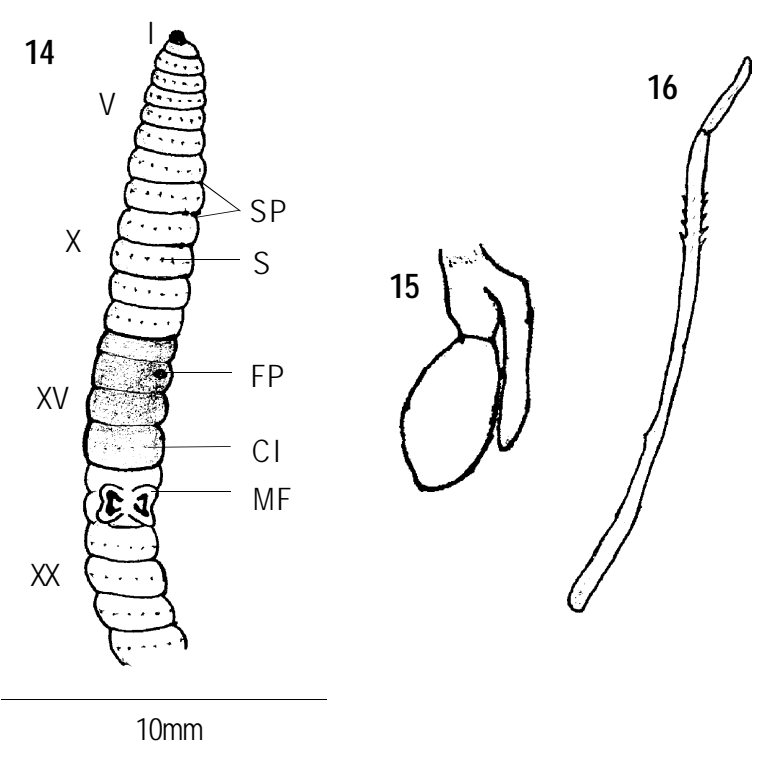

Figures 14-16. Octochaetona barnesi (Stephenson) 14 - External characters; 15 - Spermatheca (x25); 16 - Penial seta $(x 100)$
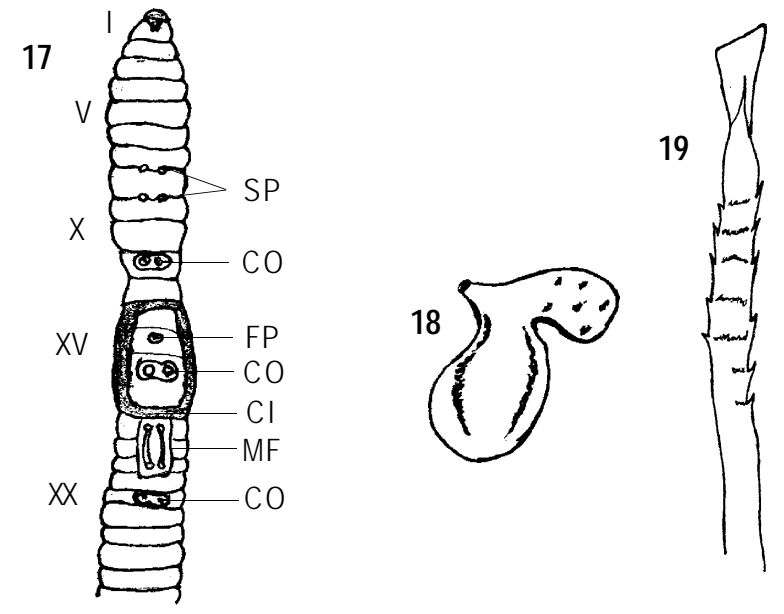

$10 \mathrm{~mm}$

Figure 17-19. Octochaetona pattoni (Michaelsen) 17 - External characters; 18 - Spermatheca (x25); 19 - Penial seta (x250)
Octochaetona pattoni (Michaelsen)

External characters

Length $60-115 \mathrm{~mm}$, diameter $2.5-3 \mathrm{~mm}, 130-155$ segments. Prostomium epilobic, tongue open. First dorsal pore 12/13. Clitellum $1 / 2$ xiii-xvi. Setae eight per segment. On viii and ix copulatory setae are surrounded by tumescences. Male genital field longitudinally oval and depressed. Male and prostatic pores minute, at a; seminal grooves straight between setal arcs of xvii and xix. Female pores paired. Spermathecal pores small, transverse slits, in 7/8/9, at a. Genital markings oval, paired; post setal on xi and on 14/15.

\section{Internal characters}

Septa 4/5, 10/11 - 12/13 muscular, 9/10 delicate, 5/6 -8/9 absent. Gizzard between septa 4/5 and 9/10. Intestine begins in xviii, typhlosole begins in xviii. Last pair of hearts in xiii. Holandric, testes and male funnels enclosed in sacs in $\mathrm{x}$ and $\mathrm{xi}$, seminal vesicles in ix and xii. Penial setae ornamented with rings of small to large teeth, ectal end expanded with sharp lateral and distal serrated edges (Ismail, 1985). Each spermatheca with a shortly stalked ental diverticulum. Copulatory setae ornamented with 12-13 transverse and concave ridges, projecting into spines on the margins of the setae, tip bluntly rounded (Ismail, 1985).

\section{External characters}

\section{Octochaetona serrata (Gates)}

Length $80-150 \mathrm{~mm}$, diameter $3-4 \mathrm{~mm}, 160-200$ segments, prostomium epilobic, tongue closed, sometimes open. First dorsal pore in 12/13. Clitellum xiii-xvi. Setae eight per segment. On vii and viii copulatory setae are surrounded by tumescences. Male genital field depressed rectangular. Male pores minute, seminal grooves almost straight between setal arc of xvii and xix. Female pores paired. Spermathecal pores large transverse slits on 7/8/9. Genital markings oval, unpaired and median on $21 / 22$, also observed on 20/21, 22/23, and 28/29.

\section{Internal characters}

Septa 4/5, 10/11-13/14 muscular, 9/10 delicate, 5/6-8/9 absent. Gizzard between septa 4/5 and 9/10. Intestine begins in xviii, typhlosole begins in xviii. Last pair of hearts in xiii. Holandric, testes and male funnels in sacs, in $\mathrm{x}$ and $\mathrm{xi}$, seminal vesicles in ix and xii, penial setae ornamented with circles of triangular teeth, tip bluntly rounded. Each spermatheca with a broad ental diverticulum. Copulatory setae ornamented with circles of fine spines, tip claw-shaped. Genital marking glands absent.

\section{Remarks}

This species is usually found in red laterite soil. 


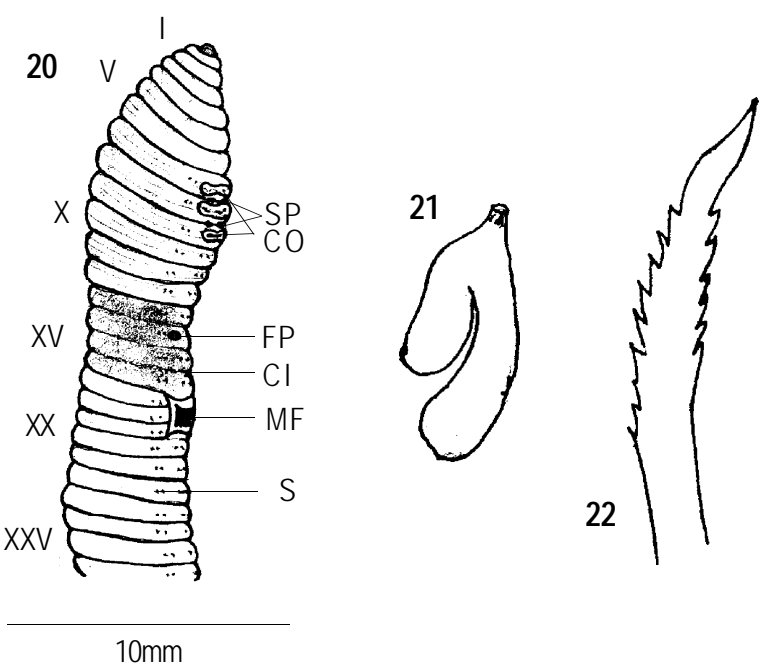

Figures 20-22. Octochaetona serrata (Gates)

20 - External characters; 21 - Spermatheca (x20); 22 - Penial seta (x200)
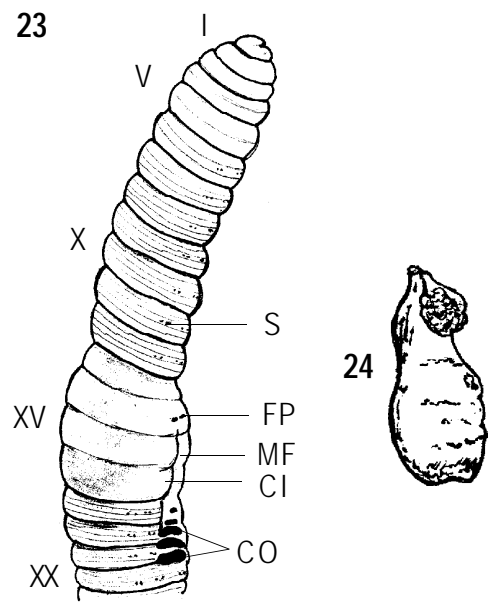

$10 \mathrm{~mm}$

Figures 23-26. Octochaetona thurstoni (Michaelsen) 23 - External characters; 24 - Spermatheca $(x 30)$; 25 - Penial seta (x80); 26 - Penial seta (x200)

\section{Octochaetona thurstoni (Michaelsen)}

External characters

Length 130-250mm, diameter 5-6mm, 195-230 segments, prostomium epilobic, tongue closed. First dorsal pore at 12/13, clitellum xiii-xvii. Male genital field slightly depressed, extending from xvii to xix. Male pores minute. Female pores on xiv. Genital markings oval, cushion-like, unpaired and median, on 16/17, 17/ 18 , and 19/20 sometimes observed further on segments 20 and 21. Setae eight per segment.

\section{Internal characters}

Septa 4/5, 7/8-12/13 muscular, 5/6/7 absent. Gizzard between septa $4 / 5$ and $7 / 8$. Intestine begins in xviii, typhlosole begins in xxiv. Last pair of hearts in xiii. Holandric, testes and male funnels free, in $\mathrm{x}$ and $\mathrm{xi}$, seminal vesicles in $\mathrm{xi}$ and $\mathrm{xii}$. Penial setae thin, hairlike, ornamented with 12-16 irregular rings of very small spines or scale-like structures, tip pointed. Each spermatheca with a shortly stalked, flattened, shaft-like multiloculate ental diverticulum, duct shorter than ampulla.

\section{Family: Eudrilidae}

Genus: Eudrilus Perrier

\section{External characters}

Eudrilus eugeniae (Kinberg)

Length 30-200mm; diameter 5-7mm; segments 145-200, colour brown to dark violet. Prostomium epilobous. Setae, eight per segment, lateral and ventral. Clitellum ventrally somewhat less strongly developed, xiii or xiv to xviii. Male pores immediately in front of 17/18. Spermathecal pores fused with the female pores, immediately behind 13/14.

\section{Internal characters}

Prostates with markedly set off narrow duct, sharply set off from copulatory sacs; these sacs with y-shaped appendages. The muscular atrium-like cavity of the spermathecae with only one proper diverticulum, fairly close to the ental end and opposite the ovisac. Ovisac with long undulating stalk, the tube which leads from the ovarian chamber opens into the ectal end of the spermathecal ampulla.

\section{Remarks}

This exotic species is used in vermicomposting units.

\section{Discussion}

About 3000 species of earthworms are reported in the world (Dash, 1988) and the Indian subcontinent is represented by 509 species under 67 genera (Julka, 1993).

The present work records three families Moniligastridae, Megascolecidae and Octochaetidae in and around Chennai. Eudrilus (Eudrilidae) is used for vermicompost production, individuals having procured these specimens from commercial centres or research institutions. The family Moniligastridae is 

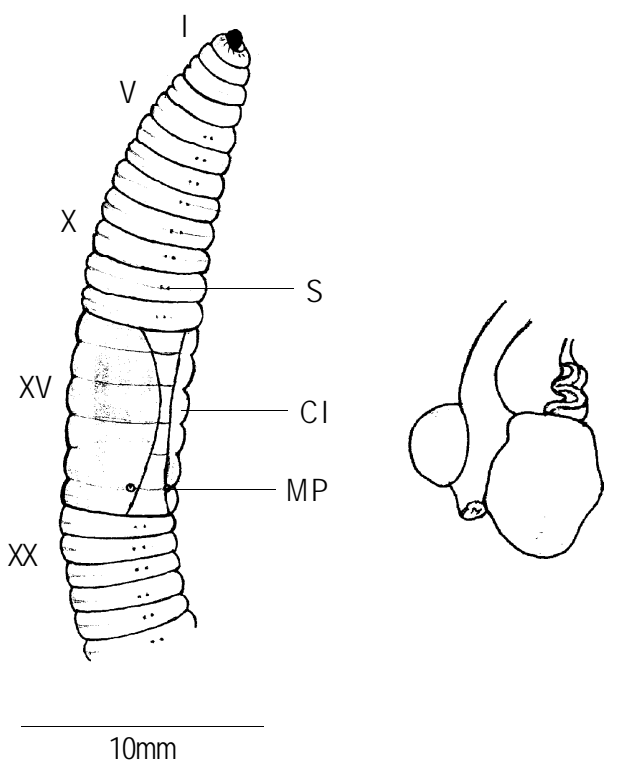

Figures 27-28. Octochaetona thurstoni (Michaelsen) 27 - External characters; 28 - Spermatheca (x20)

represented by the genus Drawida comprising Drawida scandens. The family Megascolecidae is represented by Lampito and Perionyx. Genus Lampito is largely represented by Lampito mauritii and rarely with Lampito bouchei. Genus Perionyx is represented by two species, Perionyx excavatus and Perionyx sansibaricus. Family Octochaetidae is represented by the dominant genus Octochaetona and Dichogaster. Eudrilidae is represented by Eudrilus. Octochaetona includes four species, Octochaetona barnesi, Octochaetona pattoni, Octochaetona serrata and Octochaetona thurstoni. Apart from these Ramiella pachpaharensis has been reported by Ismail (1985).

\section{References}

Dash, M.C. (1988). Fundamentals of Ecology. Tata McGraw-Hill Publishing Company Limited, New Delhi, India, 373pp.

Easton, E.G. (1982). The identity of Perichaeta lawsoni Bourne, 1886. (Syn. Megascolex curgensis Michaelsen, 1921) (Megascolecidae: Oligochaeta). Megadrilogica 4(1-2): 1-3.

Edwards, C.A. and P.J. Bohlen (1996). Biology and Ecology of Earthworms Chapman and Hall, London, 380pp.

Ismail, S.A. (1982). Scanning electron microscope observations of the penial setae of the earthworm L. mauritii. Current Science 51: 10001001 .

Ismail, S.A. (1985). Scanning electron microscope observations on the copulatory and penoial setae of the earthworm Octochaetona pattoni (Michaelsen). Current Science 54(20): 1082-1083.

Ismail, S.A. (1997). Vermicology. The Biology of Earthworms. Orient Longman Ltd., India., 92pp.

Ismail, S.A. and M. Kaleemurrahman (1981). Report on the occurrence of bioluminescence in the earthworm, L. mauritii. Current Science 50: 555 .

Jamieson, B.G.M. (1977). Preliminary descriptions of Indian earthworms (Megascolecidae: Oligochaeta) from the Palni Hills. Bulletin du Muséum National D'Histoire Naturelle., Paris $3^{\mathrm{e}} \mathrm{Ser}, \mathrm{N}^{\circ} 450$, Zool, 313: 478-502.

Julka, J.M. 1975. Notes on the earthworms from Darjeeling district, with descriptions of the two new species. Mitt. Zoological Museum Berlin, 51: 19-27.

Julka, J.M. (1976a). Studies on the earthworms collected during the Daphabum Expedition in Arunachal Pradesh, India. Record of the Zoological Survey of India 69: 229-239.

Julka. J.M. (1976b). Studies on the earthworm fauna of Orissa (India). 1. Moniligastridae and Ocnerodrilidae. Mitt. Zoological Museum, Berlin, 52: 321-329.

Julka, J.M. (1977). Contribution to the knowledge of the earthworm fauna (Oligochaeta: Annelida) of Meghalaya. Newsletter of the Zoological Survey of India 3(6): 398-400.

Julka, J.M. (1978). Studies on the earthworms fauna of Orissa (India). 2. Megascolecidae, Octochaetidae and Microchaetidae. Mitt.Zoological Museum, Berlin, 54: 185-197.

Julka, J.M. (1979). First record of Lumbricus castaneus (Savigny) from India (Lumbricidae: Oligochaeta). Journal of the Bombay Natural History Society 76: 191-192.

Julka, J.M. (1981). Taxonomic studies on the earthworms collected during the subansiri Expedition in Arunachal Pradesh, India. Records of the Zoological Survey of India.Occasional Paper No. 26: 1-37.

Julka, J.M. (1983). A new genus and species of earthworm (Octochaetidae: Oligochaeta) from South India. Geobios New Reports 2: 48-50.

Julka, J.M. (1988). Fauna of India: Megadrile Oligochaeta (earthworms). Haplotaxida: Lumbricina; Megascolecidae; Octochaetidae, Zoological Survey of India, Calcutta, 400pp.

Julka, J.M. (1993). Earthworm resources of India and their utilization in vermiculture. In: The Director, Zoological Survey of India (editor) Earthworm Resources and Vermiculture, Zoological survey of India, Calcutta, India. 51-56pp.

Stephenson, J. (1923). Oligochaeta. The Fauna of British India, including Ceylon and Burma, Taylor and Francis Ltd., London, xxiv+518pp. 